\title{
Comparative study of the presence of heavy metals utilizing epiphytic corticolous lichens in Talca city, Maule Region, Chile
}

\section{Estudio comparativo de la presencia de metales pesados utilizando líquenes epífitos corticícolas en la ciudad de Talca, Región del Maule, Chile}

\author{
Iris Pereira ${ }^{1 *}$, Jaime Tapia ${ }^{2}$, Ignacio Errázuriz ${ }^{3} \&$ Silvia Basualto 4 \\ ${ }^{1}$ Instituto de Ciencias Biológicas, Av. Lircay s/n, Universidad de Talca, Chile. \\ ${ }^{2}$ Instituto de Química y Recursos Naturales, Universidad de Talca, Talca, Chile \\ ${ }^{3}$ Escuela de Agronomía, Facultad de Ciencias Agrarias, Universidad de Talca, Chile \\ ${ }^{4}$ Centro EULA, Universidad de Concepción, Barrio Universitario s/n, Concepción, Chile. \\ *ipereira@utalca.cl
}

\begin{abstract}
The concentrations of $\mathrm{Cu}, \mathrm{Cr}, \mathrm{Fe}, \mathrm{Pb}$ and $\mathrm{Zn}$ in thallus of three species of epiphytic lichens were determined: Flavopunctelia flaventior, Phaeophyscia orbicularis and Ramalina ecklonii, collected in three sectors of Talca city (Region of Maule, Chile), which have been exposed to different human activities. The first collection of samples was carried out by Pereira $\&$ Tapia. in 1999 and those results were compared with samples collected in 2016. Metal determinations were made by flame atomic absorption spectroscopy, considering the thallus of each lichen as representative sample for analysis. The methodological validation was carried out using certified reference material (SRM-1570). The highest levels of concentration in the three sectors and for the two sampling periods were for $\mathrm{Fe}>\mathrm{Zn}>\mathrm{Pb}>\mathrm{Cu}>\mathrm{Cr}>\mathrm{Cd}$. In 1999, the range of concentrations of the heavy metals in dry wet varied 335.5-1724 $\mu \mathrm{g} / \mathrm{g}$ for iron (Fe); 40.7-209.5 $\mu \mathrm{g} / \mathrm{g}$ for zinc ( $\mathrm{Zn}$ ); 10.4-64.2 $\mu \mathrm{g} / \mathrm{g} \mathrm{for} \mathrm{lead} \mathrm{(Pb);}$ $10-28.7 \mu \mathrm{g} / \mathrm{g}$ for copper $(\mathrm{Cu}) ; 0.6-4.8 \mu \mathrm{g} / \mathrm{g}$ for chromium and $0.1-0.4 \mu \mathrm{g} / \mathrm{g}$ for cadmium $(\mathrm{Cd})$ while in 2016 the ranges were 1356.6-14280.4 $\mu \mathrm{g} / \mathrm{g}$ for iron (Fe); 26.8-179.5 $\mu \mathrm{g} / \mathrm{g}$ for zinc ( $\mathrm{Zn}) ; 13.5-102.5 \mu \mathrm{g} / \mathrm{g}$ for lead (Pb); 7.9-36.2 $\mu \mathrm{g} / \mathrm{g}$ for copper $(\mathrm{Cu}) ; 3.6-24.6 \mu \mathrm{g} / \mathrm{g}$ for chromium and not detected for cadmium $(\mathrm{Cd})$. The samples collected in 2016 generally showed higher concentration levels of $\mathrm{Fe}, \mathrm{Cu}, \mathrm{Cr}$ and $\mathrm{Pb}$ than those collected in 1999, especially those corresponding to the central area of the city of Talca. According to the results, the species that accumulated more heavy metals were $P$. orbicularis followed by $F$. flaventior and last $R$. ecklonii. It can be concluded that foliose species are potentially better candidates to be used as long-term bioindicators than the fruticose species. The downtown sector of the city is the most polluted due to the presence of tannery industries and the increase of vehicular traffic that the city has had in the last two decades as a result of agricultural development and population growth.
\end{abstract}

KEYwords: Bioindicator, Chile, heavy metals, lichens, urban contamination.

\section{RESUMEN}

Se determinó las concentraciones de $\mathrm{Cu}, \mathrm{Cr}, \mathrm{Fe}, \mathrm{Pb}$ y $\mathrm{Zn}$ en talos de tres especies de líquenes epífitos: Flavopunctelia flaventior, Phaeophyscia orbicularis y Ramalina ecklonii, colectados en tres sectores de la ciudad de Talca (Región del Maule, Chile), expuestos a diferentes actividades humanas. La primera recoleccón de muestras fue realizada por Pereira \& Tapia en 1999 y sus resultados se compararon con muestras colectadas el año 2016. Las determinaciones de metales se realizaron por espectroscopia de absorción atómica con llama, considerando para su análisis el talo de cada liquen como muestra representativa. La validación metodológica se realizó utilizando material de referencia certificado (SRM-1570). Los mayores niveles de concentración en los tres sectores y en los dos períodos de muestreo fueron para $\mathrm{Fe}>\mathrm{Zn}>\mathrm{Pb}$ $>\mathrm{Cu}>\mathrm{Cr}>\mathrm{Cd}$. En 1999, el rango de concentraciones de los metales pesados en peso seco varió: 335,5-1724 $\mu \mathrm{g} / \mathrm{g}$ para fierro (Fe); 40,7-209,5 $\mu \mathrm{g} / \mathrm{g}$ para zinc $(\mathrm{Zn}) ; 10,4-64,2 \mu \mathrm{g} / \mathrm{g}$ para plomo $(\mathrm{Pb}) ; 10-28,7 \mu \mathrm{g} / \mathrm{g}$ para cobre $(\mathrm{Cu}) ; 0,6-4,8 \mu \mathrm{g} / \mathrm{g}$ para cromo $(\mathrm{Cr}) ; 0,1-0,4 \mu \mathrm{g} / \mathrm{g}$ para cadmio $(\mathrm{Cd})$, mientras que en el 2016 los rangos fueron: 1356,6-14280,4 $\mu \mathrm{g} / \mathrm{g}$ para fierro (Fe); 26,8-179,5 $\mu \mathrm{g} / \mathrm{g}$ para zinc $(\mathrm{Zn}) ; 13,5-102,5 \mu \mathrm{g} / \mathrm{g}$ para plomo $(\mathrm{Pb}) ; 7,9-36,2 \mu \mathrm{g} / \mathrm{g}$ para cobre $(\mathrm{Cu}) ; 3,6-24,6 \mu \mathrm{g} / \mathrm{g}$ para cromo $(\mathrm{Cr})$ y no detectado para cadmio $(\mathrm{Cd})$. Las muestras colectadas el año 2016 presentaron en general mayores niveles de concentración de $\mathrm{Fe}, \mathrm{Cu}, \mathrm{Pb}$ y $\mathrm{Cr}$ que las colectadas el año 1999, especialmente las correspondientes a la zona central de la ciudad de Talca. De acuerdo a los resultados, las especies que más metales pesados acumularon fueron $P$. orbicularis seguidas por $F$. flaventior y $R$. ecklonii. Se puede concluir que las especies foliosas son potencialmente las 
Study of heavy metals in lichens of Talca city: PerEIRA, I. ET AL.

mejores candidatas para ser usadas como bioindicadores de largo plazo que la especie fruticosa. El sector céntrico de la ciudad es el más contaminado debido a la presencia de industrias de curtiduría y al aumento de tráfico vehicular que ha tenido la ciudad en las últimas dos décadas producto del desarrollo agrícola y el crecimiento de la población.

Palabras clave: Bioindicator, Chile, contaminación urbana, líquenes, metales pesados.

\section{INTRODUCTION}

Lichens have been used worldwide as indicators of the presence of a high variety of atmospheric contaminants especially in urban and suburban areas. They are extremely sensitive symbiotic organisms which react to even slightly polluted air and they have certain required characteristics for an ideal biomonitor: large geographical ranges allowing comparison of metal concentration from diverse regions; a morphology which does not vary with seasons, thus enable accumulation to occur throughout the year (Markert 1993, Loppi et al. 2000). Considering that the lichens have no root, their mineral nutrition depends mainly on atmospheric inputs due to that lack of protective cuticle and stomata, thalli can accumulate mineral elements, including heavy metals, at levels exceeding their metabolic requirements. The accumulation of heavy metals is one of the most widely studied aspects of modern lichenology, because of its importance to biomonitoring (Nimis et al. 2001, Kinalioglu et al. 2006). Lichens accumulate heavy metals to a very high degree, with concentrations reflecting environmental levels of these elements (Herzig et al. 1989). Talca city is situated in Maule Region, is mostly agricultural, with some preserved woodlands, tannery industries and during the last two decades has had a high increase of vehicular traffic. Due to the input of heavy metals as product of these activities and the input of particulate material in suspension product of the earthquake registered in 2010, the purpose of this study is to find out if these factors determined the increase of the concentration of these metals in the same lichen species and sectors studied previously. The choice of these metals is due to the existence of other investigations in other types of environmental matrices in the Maule Region (Tapia et al. 2009, 2010), where the presence of $\mathrm{Cu}$, $\mathrm{Cr}$ and especially $\mathrm{Pb}$ in the environment has been reported. $\mathrm{Fe}$ and $\mathrm{Pb}$ are normally present in the environment and are good indicators of human activity (Backor \& Loppi 2009). The aims of this study were to determine the heavy metals concentrations of $\mathrm{Cr}, \mathrm{Cu}, \mathrm{Fe}, \mathrm{Pb}$ and $\mathrm{Zn}$ in the lichen thalli of the three species of epiphytes lichen: Flavopunctelia flaventior (Stirton) Hale, Phaeophyscia orbicularis (Necker) Moberg y Ramalina ecklonii (Spreng.) Mey. et Flot. and to compare with those obtained 17 years ago from of the same sectors and in the same species in Talca city, Chile (Pereira \& Tapia 1999).

\section{MATERIALS AND METHODS}

STUDY AREA AND COLLECTION OF LICHEN MATERIAL

The lichen material was collected from three sectors in Talca city, selected considering the level of vehicular traffic, the presence of tannery industries in each one. The three sectors are exposed to different levels of contamination sources (Fig. 1):

Sector 1: South zone, residential, moderate traffic, presence of tannery industries. It collected 9 samples in 1999 and 8 in 2016.

Sector 2: Central zone, center city, commercial, with high traffic and influence of contaminants of Sector 1. It collected 7 samples in 1999 and 7 in 2016.

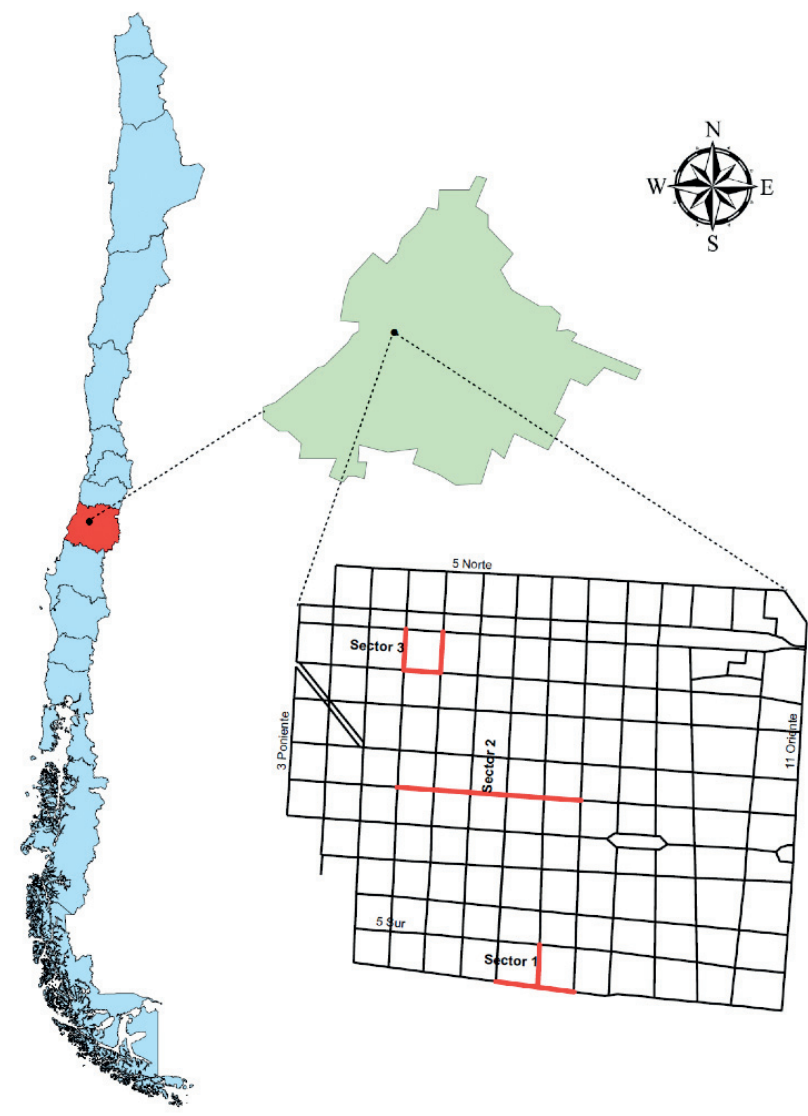

Figure 1. Map of Chile that show the Maule Region (left), Talca province (up to the center) and the map that show the studied area (right). / Mapa de Chile que muestra la Región del Maule (izquierda), Provincia de Talca (arriba al centro) y mapa que muestra el área estudiada (derecha). 
Sector 3: North zone of the city, residential, low traffic and no influence of industrial activities. It collected 8 samples in 1999 and 8 in 2016.

The lichen samples were obtained from bark using a Teflon spatula to avoid metal instrumental contamination. The phorophytes were Melia azedarach L., Acer negundo L., Prunus cerasifera Ehrh., Robinia pseudoacacia L., which have been introduced as ornamental in the area. Samples of each lichen species were deposited in Talca University Herbarium.

PROCESSING OF THE SAMPLES FOR THE DETERMINATION OF METALS Lichen samples were labeled and lyophilized, ground and homogenized for chemical treatment. For the analysis, 0.5 g samples were weighed and added under hood $2 \mathrm{ml}$ of bidistilled water and $10 \mathrm{ml}$ of nitric acid p.a. The solutions were heated on a hotplate with constant stirring, to near dryness. Subsequently, the solutions were filtered using 0.45 $\mu \mathrm{m}$ porosity filters. The filtrate was brought to a final volume of $50 \mathrm{ml}$ with bidouble distilled water. Metals determinations were performed by atomic absorption spectroscopy with flame (air/acetylene) (UNICAM spectrophotometer mod. 969). The instrument was calibrated with standard solutions of Fisher Scientific International Company. All determinations were performed considering their target solutions. The validation of the methodology was performed using certified reference material from the National Institute of Standards and Technology SRM-1570 (spinach).

Table 1 shows the results of $\mathrm{Cu}, \mathrm{Cr}, \mathrm{Fe}, \mathrm{Pb}$ and $\mathrm{Zn}$ measurements on the certified reference material. The repeats in the reference material showed good accuracy for these concentration levels, with relative errors ranging from $0.77 \%$ for $\mathrm{Cu}$ to $33.3 \%$ for $\mathrm{Pb}$.

TABLE 1. Concentration of $\mathrm{Cu}, \mathrm{Cr}, \mathrm{Fe}, \mathrm{Pb}$ and $\mathrm{Zn}\left(\mathrm{mg} \mathrm{kg}^{-1}\right)$ in certified reference material (SRM - 1570). / Concentración de $\mathrm{Cu}, \mathrm{Cr}, \mathrm{Fe}, \mathrm{Pb}$ y Zn $\left(\mathrm{mg} \mathrm{kg}^{-1}\right)$ en material certificado (SRM-1570).

\begin{tabular}{ccccc}
\hline Element & $\begin{array}{c}\text { Certified } \\
\text { CONCENTRATION }^{\mathrm{a}}\end{array}$ & $\begin{array}{c}\text { Observed } \\
\text { ConCEnTRATION }^{\mathrm{a}}\end{array}$ & $\begin{array}{c}\text { Rel. error } \\
(\%)^{\mathrm{b}}\end{array}$ & $\begin{array}{c}\text { ReCOVERY } \\
(\%)\end{array}$ \\
\hline $\mathrm{Cu}$ & 13.0 & 13.1 & 0.77 & 100.8 \\
$\mathrm{Cr}$ & 4.6 & 4.9 & 6.52 & 106.5 \\
$\mathrm{Fe}$ & 550 & 558 & 558 & 101.4 \\
$\mathrm{~Pb}$ & 1.2 & 1.6 & 33.3 & 133.3 \\
$\mathrm{Zn}$ & 50.0 & 51.3 & 2.60 & 102.6 \\
\hline
\end{tabular}

${ }^{a}$ The concentrations are expressed in $\mathrm{mg} \mathrm{kg}^{-1}$ (dry weight). / Las concentraciones están expresadas en $\mathrm{mg} \mathrm{kg}^{-1}$ (peso seco).

${ }^{\mathrm{b}}$ Accuracy of data, expressed as relative error. Exactitud de los datos expresada como error relativo.

TABLE 2. Concentration of heavy metals in lichens of Talca city, Maule Region, Chile. / Concentración de metales pesados en líquenes de la ciudad de Talca, Región del Maule, Chile.

\begin{tabular}{|c|c|c|c|c|c|c|c|c|}
\hline Sector / Species & $\begin{array}{c}\mathrm{N} \\
1999\end{array}$ & $\begin{array}{c}\mathrm{N} \\
2016\end{array}$ & $\begin{array}{c}\mathrm{Cu} \\
(\mu \mathrm{g} / \mathrm{g} \text { dry wt }) \\
1999-2016\end{array}$ & $\begin{array}{c}\mathrm{Cr} \\
(\mu \mathrm{g} / \mathrm{g} \text { dry wt) } \\
1999-2016\end{array}$ & $\begin{array}{c}\mathrm{Cd} \\
(\mu \mathrm{g} / \mathrm{g} \text { dry wt) } \\
1999-2016\end{array}$ & $\begin{array}{c}\mathrm{Fe} \\
(\mu \mathrm{g} / \mathrm{g} \text { dry wt)} \\
1999-2016\end{array}$ & $\begin{array}{c}\mathrm{Pb} \\
(\mu \mathrm{g} / \mathrm{g} \text { dry wt) } \\
1999-2016\end{array}$ & $\begin{array}{c}\mathrm{Zn} \\
(\mu \mathrm{g} / \mathrm{g} \text { dry wt) } \\
1999-2016\end{array}$ \\
\hline \multicolumn{9}{|l|}{ Sector 1: South } \\
\hline Flavopunctelia flaventior & 4 & 3 & $16.0-33.4$ & $0.9-3.6$ & $0.2-\mathrm{ND}$ & $309.0-1463.9$ & $24.2-19.8$ & $45.6-139.3$ \\
\hline Phaeophyscia orbicularis & 2 & 2 & $28.7-24.2$ & $4.8-6.4$ & $0.3-\mathrm{ND}$ & $1724.0-6004.5$ & $38.8-13.5$ & $104.9-109.1$ \\
\hline Ramalina ecklonii & 3 & 3 & $12.9-7.9$ & $1.2-12.2$ & $<0.1-\mathrm{ND}$ & $384.6-1437.8$ & $10.4-28.9$ & 40.7 - ND \\
\hline \multicolumn{9}{|l|}{ Sector 2: Center city } \\
\hline Flavopunctelia flaventior & 4 & 4 & $14.9-18.3$ & $0.9-7.4$ & $0.4-\mathrm{ND}$ & $514.7-4734.2$ & $69.2-102.5$ & $75.4-179.5$ \\
\hline Phaeophyscia orbicularis & 3 & 3 & $19.2-36.2$ & $4.3-24.6$ & $0.3-\mathrm{ND}$ & $1014.6-7549.0$ & $36.5-84.5$ & $209.5-151.2$ \\
\hline Ramalina ecklonii & 0 & 0 & $\mathrm{~W} / \mathrm{S}-\mathrm{W} / \mathrm{S}$ & $\mathrm{W} / \mathrm{S}-\mathrm{W} / \mathrm{S}$ & $\mathrm{W} / \mathrm{S}-\mathrm{W} / \mathrm{S}$ & $\mathrm{W} / \mathrm{S}-\mathrm{W} / \mathrm{S}$ & $\mathrm{W} / \mathrm{S}-\mathrm{W} / \mathrm{S}$ & $\mathrm{W} / \mathrm{S}-\mathrm{W} / \mathrm{S}$ \\
\hline \multicolumn{9}{|l|}{ Sector 3: North } \\
\hline Flavopunctelia flaventior & 4 & 3 & $19.1-14.6$ & $0.9-9.1$ & $0.3-\mathrm{ND}$ & $500.0-6362.3$ & $65.7-32.2$ & $76.6-76.5$ \\
\hline Phaeophyscia orbicularis & 2 & 3 & $17.8-21.7$ & $3.7-13.9$ & $0.2-\mathrm{ND}$ & $1245.0-14280.4$ & $38.5-34.9$ & $80.0-112.1$ \\
\hline Ramalina ecklonii & 2 & 3 & $10.0-9.4$ & $0.6-6.9$ & 0.2 - ND & $335.5-1356.6$ & $26.9-13.9$ & $49.5-26.8$ \\
\hline
\end{tabular}

$\mathrm{N}$ : Number of samples. ${ }^{(1)}$ Results expressed in dry material. W/S: without sample. ND: not detected. / N: Número de muestras. ${ }^{(1)}$ Resultados expresados en materia seca. W/S: sin muestra. ND: no detectado. 


\section{RESULTS}

In Table 2, it shows data of heavy metals content in lichen species from three sectors of the city of Talca in 1999 and 2016.

The following graphs show the content of heavy metals accumulated in the lichen thalli situated in three sectors of Talca city in the Maule Region. Concentrations given for each metal corresponds to a representative sample of the total of collected material.

The $\mathrm{Cu}$ concentration tends to increase in the three sectors in the foliose species in 2016, nevertheless, the uptake of this element does not occur similarly in these two species and the range vary from 14.6-36.2 $\mu \mathrm{g} / \mathrm{g}$ dry wt. On the other hand, in the same year, the $\mathrm{Cu}$ concentration was lower than to the registered in 1999 in the fruticose species in the sectors 1 and 3 (Fig. 2).

In 1999, the $\mathrm{Cu}$ concentration varied from 14.9-28.7 $\mu \mathrm{g} / \mathrm{g}$ dry wt in the foliose species by considering the three sectors studied. In the fruticose species, the concentration varied $10-12.9 \mu \mathrm{g} / \mathrm{g}$ dry wt in the sectors 1 and 3 , where was present (Fig. 2).

The $\mathrm{Cr}$ concentration increased in the three studied sectors, in Flavopunctelia flaventior and Phaeophyscia orbicularis in 2016, becoming higher in the sector 2 (center city), where it reaches a concentration of $24.6 \mu \mathrm{g} / \mathrm{g}$ dry wt in the lichen thallus of $P$. orbicularis, five times major to that registered in 1999. It is noteworthy that this element increase gradually in both species from its source, (tannery industries) located in the south sector of the city toward the center of this, for then to decrease in the north sector. In this same year, the concentration of this metal varied 3.6$24.6 \mu \mathrm{g} / \mathrm{g}$ dry wt in the foliose species considering the three studied sectors, while that in $R$. ecklonii varied 6.9-12.2 $\mu \mathrm{g} / \mathrm{g}$ dry wt in the sectors 1 and 3 , where this species was present (Fig. 3).

In 1999, the $\mathrm{Cr}$ concentration varied in a range: 0.9-12 $\mu \mathrm{g} / \mathrm{g}$ dry wt and 0.9-3.7 $\mu \mathrm{g} / \mathrm{g}$ dry wt in the sectors 1 and 3 respectively considerate the three studied lichen species. In

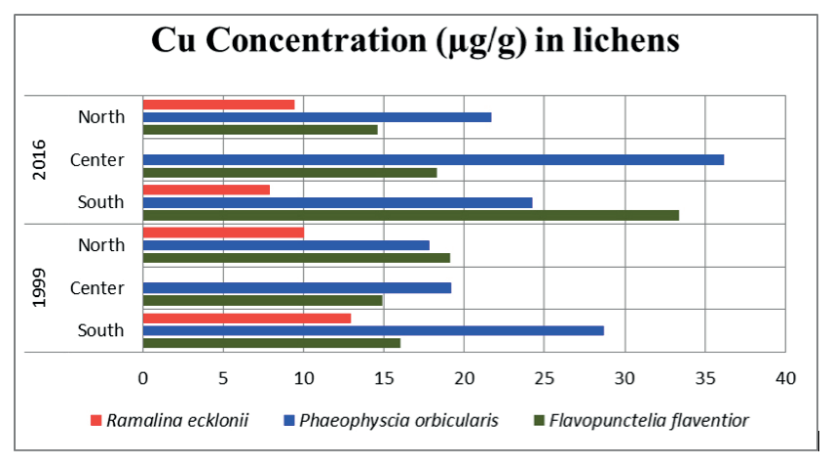

Figure 2. Cu concentration in lichens of Talca city in 1999 and 2016. / Concentración de Cu en líquenes de la ciudad de Talca en 1999 y 2016. the sector 2 , instead, the range varied between $0.9-4.3 \mu \mathrm{g} / \mathrm{g}$ dry wt considerate only the foliose species since Ramalina ecklonii not was detected in this sector in this year (Fig. 3).

The Fe concentration it increased in the three sectors in the two foliose species in 2016 . This increase is proportional from the south sector to north sector. The species that accumulate the highest concentration was Phaeophyscia orbicularis. In 2016, the concentration increase significantly in the two foliose species varied 1463.9-14280.4 $\mu \mathrm{g} / \mathrm{g}$ dry wt and in the case of $R$. ecklonii, the concentration of this element varied 66.6-1437.8 $\mu \mathrm{g} / \mathrm{g}$ dry wt (Fig. 4).

In 1999, the concentration of Fe varied 309-1724 $\mu \mathrm{g} / \mathrm{g}$ dry wt by considering only the foliose species in the three sectors sampled. For the case of $R$. ecklonii that only was present in the sector 1 (south) and 3 (north), the Fe concentration varied 335.5-384.5 $\mu \mathrm{g} / \mathrm{g}$ dry wt (Fig. 4).

With respect to the $\mathrm{Pb}$ concentration in the lichens, it can observe that the highest concentration of this metal is concentrated in the sector 2 (center city) in the two foliose species in 2016. In this same year, the lowest concentration is register in Ramalina ecklonii, fruticose species present only in the sectors 1 and 3 instead in the sector 2 this species was absent (Fig. 5).

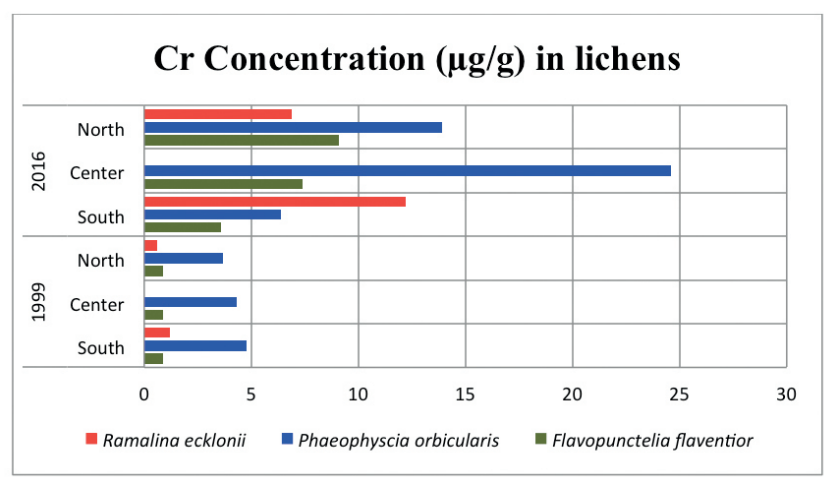

Figure 3. Cr concentration in lichens of Talca city in 1999 and 2016. / Concentración de Cr en líquenes de la ciudad de Talca en 1999 y 2016.

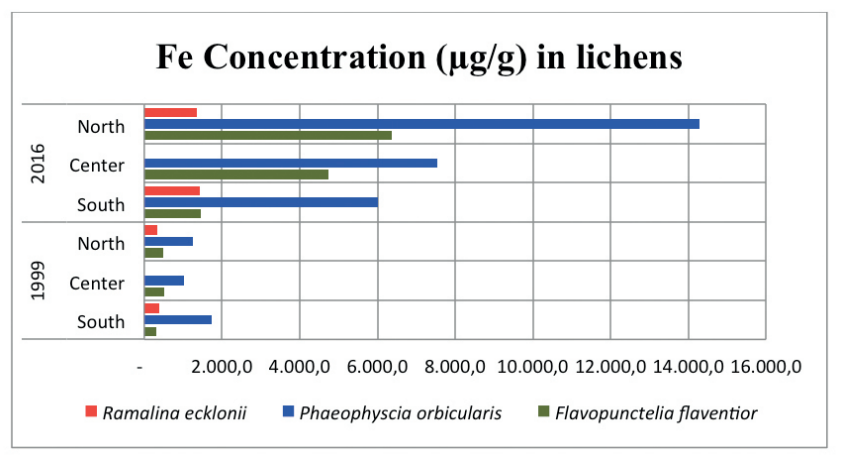

Figure 4. Fe concentration in lichens of Talca city in 1999 and 2016. / Concentración de Fe en líquenes de la ciudad de Talca en 1999 y 2016. 
In 1999, the concentration of this elemental varied of $24.2-69.2 \mu \mathrm{g} / \mathrm{g}$ dry wt in the foliose species present in the three studied sectors instead the range of this element in Ramalina ecklonii varied 13.9-28.9 $\mu \mathrm{g} / \mathrm{g}$ dry wt in 2016 (Fig. 5).

The $\mathrm{Zn}$ concentration also increased in two foliose species of the three studied sectors in 2016, but the species that more $\mathrm{Zn}$ accumulated was Flavopunctelia flaventior, except in the sector 3. In this year, instead in the foliose species varied 76.5-179.5 $\mu \mathrm{g} / \mathrm{g}$ dry wt while in $R$. ecklonii register a concentration $26.8 \mu \mathrm{g} / \mathrm{g}$ dry wt only in the sector 3 (north) since in the others sectors no was detected (Fig. 6).

In 1999, the range of accumulation varied 46.6-209.5 $\mu \mathrm{g} / \mathrm{g}$ dry wt, in the foliose species in the three sampled sectors, while that in $R$. ecklonii varied 40.7-49.5 $\mu \mathrm{g} / \mathrm{g}$ dry wt in the sectors 1 and 3 (Fig. 6).

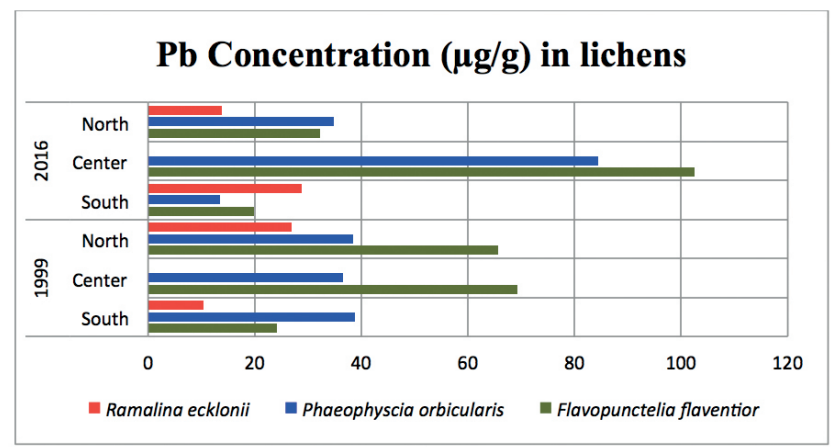

Figure 5. Pb concentration in lichens of Talca city in 1999 and 2016. / Concentración de $\mathrm{Pb}$ en líquenes de la ciudad de Talca en 1999 y 2016.

\section{$\mathrm{Zn}$ Concentration $(\mu \mathrm{g} / \mathrm{g})$ in lichens}

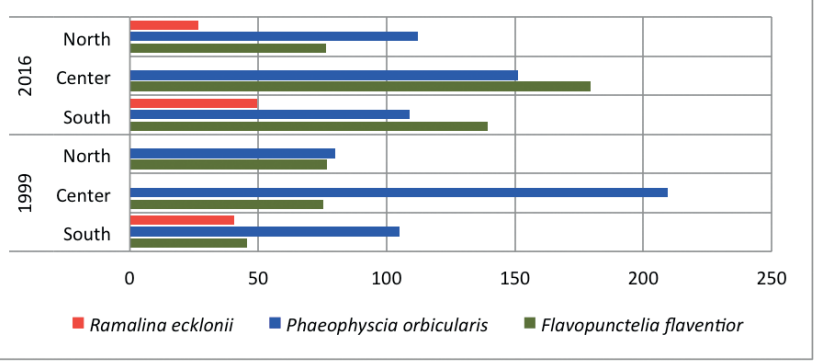

Figure 6. Zn concentration in lichens of Talca city in 1999 and 2016. / Concentración de Zn en líquenes de la ciudad de Talca en 1999 y 2016.

\section{DISCUSSION}

Accumulation of metals differs with species form of growth of the lichens and also with respect to location of the different sectors inside the city.

Of the two species foliose used in this study
Flavopunctelia flaventior and Phaeophyscia orbicularis, $F$. flaventior is the species that more accumulated heavy metals. This indicates that the growth form of thalli and degree of thallus adhesion to the substrate has a significant impact on metal concentrations in lichens.

In general, the metal contents can be grouped depending of their absolute contents in the samples. The identified groups were elements with elevated concentrations ( $\mathrm{Fe}$ and $\mathrm{Zn})$; moderate concentrations $(\mathrm{Pb}$ and $\mathrm{Cu})$ and very low concentrations ( $\mathrm{Cr}$ and $\mathrm{Cd}$ ) (Table 2).

If it is compared the normal levels $\mathrm{Fe}, \mathrm{Zn}, \mathrm{Pb}$ and $\mathrm{Cu}$ of plants growing in unpolluted areas adjacent to urban ecosystems (nature reserves) in Russia and that could be considered as baseline (Meysurova \& Notov, 2016), these vary in the following ranges: $50-250 \mu \mathrm{g} / \mathrm{g}$ dry wt for iron (Fe); 20-200 $\mu \mathrm{g} / \mathrm{g}$ dry wt for zinc (Zn); 2-10 $\mu \mathrm{g} / \mathrm{g}$ dry wt for lead $(\mathrm{Pb}) ; 5-20 \mu \mathrm{g} / \mathrm{g}$ dry wt for copper $(\mathrm{Cu})$ respectively while, the levels of these same heavy metals determinate in this study were: $1463.9-14280.4 \mu \mathrm{g} / \mathrm{g}$ dry wt for iron (Fe); $76,5-179.5 \mu \mathrm{g} / \mathrm{g}$ dry wt for zinc (Zn); 13,5-102.5 $\mu \mathrm{g} / \mathrm{g}$ dry wt for lead $(\mathrm{Pb})$ and 7,9-56,2 $\mu \mathrm{g} / \mathrm{g}$ dry wt for copper $(\mathrm{Cu})$ respectively in foliose lichen species. In general, the ranges of these elements in Talca city in 2016 detected in foliose lichen species were 3 to 10 times greater than in plants come from of non-polluted areas.

When comparing the ranges of heavy metals as $\mathrm{Cd}$, $\mathrm{Cr}, \mathrm{Cu}, \mathrm{Pb}$ and $\mathrm{Zn}$ found in Parmelia caperata reported by Ite et al. (2016) of governmental areas from Eket and Ibeno, Akwa Ibom State, Nigeria, these elements varied: 0.006-0.092 $\mu \mathrm{g} / \mathrm{g}$ dry wt for cadmium (Cd); 0.055-6.724 $\mu \mathrm{g} / \mathrm{g}$ dry wt for chromium $(\mathrm{Cr}) ; 10.860-19.980 \mu \mathrm{g} / \mathrm{g}$ dry wt for copper $(\mathrm{Cu})$.; 0.841-0.998 $\mu \mathrm{g} / \mathrm{g}$ dry wt for lead $(\mathrm{Pb})$; $53.760-83.960 \mu \mathrm{g} / \mathrm{g}$ dry wt for zinc (Zn) respectively, while that in foliose species in Talca in 2016, these same metals ranged between: no detected for cadmium $(\mathrm{Cd})$; 3.6-24.6 $\mu \mathrm{g} / \mathrm{g}$ dry wt for chromium $(\mathrm{Cr}) ; 14.6-33.4 \mu \mathrm{g} / \mathrm{g}$ dry wt for copper $(\mathrm{Cu}) ; 13.5-102.5 \mu \mathrm{g} / \mathrm{g}$ dry wt for lead $(\mathrm{Pb})$ and $76.5-179.5 \mu \mathrm{g} / \mathrm{g}$ dry wt for zinc $(\mathrm{Zn})$ respectively. All the concentrations of these metals in Talca city were higher than those registered in governmental areas of Nigeria in the foliose species used. Our results allow us affirm that Talca city has significant levels of atmospheric contamination derived mainly from anthropogenic sources, whose are exposed in the results.

In basis to our results, Fe and $\mathrm{Zn}$ concentrations are the ones that reached the highest concentrations while the $\mathrm{Cr}$ concentration was the lowest in foliose lichens in 2016. This is consistent also with published data for foliose lichens in the Giresun city, Turkey (Kinalioglu et al. 2006).

In Europe, the heavy metal concentrations of $\mathrm{Cd}, \mathrm{Cu}, \mathrm{Fe}$, $\mathrm{Pb}$ and $\mathrm{Zn}$ measured in a Hypogymnia physodes epiphytic foliose lichen in a suburban area of Helsinki, Vuosaeeri, Finland (Lodenius et al. 2010) revealed the following concentrations: $0.32-1.5 \mathrm{mg} \mathrm{kg}^{-1}$ dry wt for Cd; $5-15 \mathrm{mg}$ 
$\mathrm{kg}^{-1}$ dry wt for $\mathrm{Cu}$; $440-4000 \mathrm{mg} \mathrm{kg}^{-1}$ dry wt for Fe; $2.8-16$ $\mathrm{mg} \mathrm{kg}^{-1}$ dry wt for $\mathrm{Pb}$ and $72-150 \mathrm{mg} \mathrm{kg}^{-1}$ dry wt for $\mathrm{Zn}$, while that in foliose species in Talca in 2016, these same metals ranged between: no detected for Cd; $14.6-33.4 \mu \mathrm{g} / \mathrm{g}$ dry wt for $\mathrm{Cu} ; 1463.9-14280.4 \mu \mathrm{g} / \mathrm{g}$ dry wt for Fe; 13.5 $102.5 \mu \mathrm{g} / \mathrm{g}$ dry wt for $\mathrm{Pb}$ and $76.5-179.5 \mu \mathrm{g} / \mathrm{g}$ dry wt for $\mathrm{Zn}$ respectively.

The $\mathrm{Cu}$ concentrations were twice as high as those recorded in Vuosaeeri, Finland. They are also positively correlated with central part of the city due to high vehicular traffic. The particles of soil are the main cause of $\mathrm{Cu}$ in the atmosphere ((Richardson et al. 2001) which means that the dust caused by vehicular traffic explains in part our results.

The $\mathrm{Fe}$ and $\mathrm{Pb}$ concentrations registered in Talca, Chile were notoriously higher than those registered in Vuosaeeri, Finland in the order of 4-5 times higher.

The $\mathrm{Zn}$ concentration instead was more or less of the same order of magnitude in Talca, Chile as in Vuosaeeri, Finland.

In South America, there is limited information about the determination of heavy metals in lichens in urban cities. Here, the case of Bariloche city, Argentina is analyzed, a non-industrial tourist city, whose levels of $\mathrm{Cr}, \mathrm{Zn}$ y $\mathrm{Fe}$ in urban sites were: $0-2.31 \mu \mathrm{g} / \mathrm{g}$ dry wt for chromium $(\mathrm{Cr})$; 0-29.2 $\mu \mathrm{g} / \mathrm{g}$ dry wt for zinc ( $\mathrm{Zn}$ ) and 2325-2862 $\mu \mathrm{g} / \mathrm{g}$ dry wt for iron (Fe) respectively (Ribeiro-Guevara et al., 1995), while in Talca city in 2016, the concentration of these same elements in foliose species were: 3.6-24.6 $\mu \mathrm{g} / \mathrm{g}$ dry wt for chromium (Cr); 76,5-175,5 $\mu \mathrm{g} / \mathrm{g}$ dry wt for zinc (Zn) and $1463.9-14280.4 \mu \mathrm{g} / \mathrm{g}$ dry wt for iron (Fe) respectively. When comparing, the concentrations of these three elements, it can observe that all these in the Talca city were superior to those of Bariloche city.

The Fe and $\mathrm{Zn}$ concentrations detected in the Talca city, could be due to the high vehicular traffic that to experimented the city in the two last decades. The Zn particles present in the lichen thalli of Talca city could due to from wear of automobile tires, lubricating oils and brake pads according by (Garty, 1993, Garty et al. 1993).

The greater accumulation of $\mathrm{Cr}$ in the central zone of Talca city seem to be related the dominance of the direction of the wind, being this south or southwest (Cabello 2009). Since that the tanneries industries are located in the south of the city and use high quantities of chromium in its industrial processes. Of this way the largest accumulation of this element is concentrated in lichens located in the center of the city. Also this high $\mathrm{Cr}$ concentration in lichens could be related to high vehicular traffic, since this metal is a common additive in unleaded gasoline, a component of antifreeze and parts of automobile bodies (Garty et al., 1993) or wood preservatives situated near of the city.

Phaeophyscia orbicularis and Flavoparmelia flaventior are species that have a high rate of accumulation of the following $\mathrm{Fe}, \mathrm{Zn}$ and $\mathrm{Cr}$ metals while for $\mathrm{Pb}$, it seems to be an element capable of being removed by some metabolic mechanism present in the lichen thallus (Sarret et al. 1998).

\section{ACKNOWLEDGEMENTS}

The authors acknowledge support from Project PIEI: Química y Bio-orgánica en Recursos Naturales and to Instituto de Ciencias Biológicas, University of Talca, Talca, Chile.

\section{REFERENCES}

BACKOR, M., LoppI, S. 2009. Interactions of lichens with heavy metals. Biologia Plantarum 53(2): 214-222.

Cabello, A.M. 2009. Características geohistóricas de la ocupación del espacio en la vertiente occidental de la Cordillera de la Costa, Provincia de Talca, Región del Maule, Chile. Revista Ambiente Total 2: 1-14.

GARTY, J. 1993. Lichen as biomonitors for heavy metal pollution. In: Market, B. (ed.). Plants as Biomonitors. pp. 193-263. VCH Verlag, Weinheim.

Garty, J., Karary, Y., Harel, J. 1993. The impact of air pollution on the integrity of cell membranes and chlorophyll in the lichen Ramalina duriaei (De Not.) Bagl. transplanted to industrial sites in Israel. Environmental Contamination and Toxicology 24: 455-450.

Herzig, R., Lebendörfer, L., Urech, M., Amman, K. 1989. Passive Biomonitoring with lichens as a part of an integrated biological measuring system for biomonitoring air pollution in Switzerland. International Journal Environmental Analytical Chemistry 35: 43-57.

Ite, A.E., Ubong, U.U., Etesin, U.M., Nsi, E.W., Ukpong, E.J., Ekanem, A.N., Ufot, U.F., IвоK, U.J. 2016. Heavy metals in epiphytic lichens and Mosses of Oil-Producing Commities of Eket and Ibeno, Akwa Ibom State-Nigeria. American Journal of Environmental Protection 4(2): 38-47.

Kinalioglu, K., Horuz, A., Güraykutbay, H., Bilgin, R., Yalcin, E. 2006. Accumulation of some heavy metals in lichens in Giresun city, Turkey. Ekológica (Bratislavia) 25(3): 306313.

Lodenius, M., Kuiskinen, J., Tulisalo, E. 2010. Metal levels in an epiphytic lichen as indicators of air quality in a suburb of Helsinki, Finland. Boreal Environmental Research 15: 446-452.

Loppi, S., Putorti, E., Pirintsos, S.A., De Dominicis, V. 2000. Accumulation of heavy metals in epiphytic lichens near a municipal solid waste incinerator (Central Italy), Environmental Monitoring Assessment 61: 361-371.

MARKerT, B. 1993. Interelement correlations detectable in plant samples based on data from reference materials and highly accurate research samples. Fresenius Journal of Analytical Chemistry $345:$ 318-322.

Meysurova, A.F., Notov, A.A. 2016. Metal contents in lichens from nature reserves adjacent to urban ecosystems. Journal of Applied Spectroscopy 83(5): 832-839.

Nimis, P.L., Castillo, M., Perotti, M. 2001. Lichens biomonitors for heavy metal pollution: a case study at La Spezia $(\mathrm{N}$ 
Italy). In: Markert, B. (ed.), Plants as Biomonitors, pp. 265-284. New York.

Pereira, I., Tapia, J. 1999. Líquenes epífitos como bioindicadores ambientales de la presencia de metales pesados. Información Tecnológica 10(4): 143-147.

Ribeiro Guevara, S., Arribére, M.A., Calvelo, S., Román Ross, G. 1995. Elemental composition of lichens at Nahuel Huapi National Park, Patagonia, Argentina. Journal of Radioanalytical and Nuclear Chemical Articles 198(2): 437-448.

Richardson, G.M., Garrett, R., Mitchell, I., Mah-Paulson, M., Hackbarth, T. 2001. Critical review on natural global and regional emissions of six trace metals to the atmosphere. Risklogie Scientific Services. Inc. 52 pp.

Sarret, G., Manceau, A., Cuny, D., Van Haluwyn, Ch.,
Déruelle, S., Hazemann, J-L., Soldo, Y., Eybert-Bérard, L., Menthonnex, J-J. 1998. Mechanisms of Lichen Resistance of Metallic Pollution. Environmental Science \& Technology 32: 3325-3330.

Tapia, J., Bertrán, C., Araya, C., Astudillo, M.J., VargasChacoff, L., Carrasco, G., Val

DERRAMA, A., Letelier, L. 2009. Study of the copper, chromium and lead content in Mugil cephalus and Eleginops maclovinus obtained in the mouths of the Maule and Mataquito rivers (Maule Region, Chile). Journal Chilean Chemical Society 54(1): 36-39.

Tapia, J., Vargas-Chacoff, L., Bertran, C., Carrasco, G., Torres, F., Pinto, R., Urzua, S., Valderrama, A., Letelier, L. 2010. Study of the content of cadmium, chromium and lead in bivalve molluscs of the Pacific Ocean (Maule Region, Chile). Food Chemistry 121: 666-671.

Recibido: 10.03 .2017

Aceptado: 27.03 .2018 